\title{
Ammonia Assimilation in Rhizobium japonicum Colonial Derivatives Differing in Nitrogen-fixing Efficiency
}

\author{
By R. G. UPCHURCH AND G. H. ELKAN \\ Department of Microbiology, North Carolina State University, \\ Raleigh, North Carolina 27607, U.S.A.
}

(Received 14 July 1977; revised 4 October 1977)

\begin{abstract}
Ammonia assimilatory activities were investigated in cultures of small, efficient nitrogenfixing derivatives (110-I, 76-Ns) and large, inefficient nitrogen-fixing derivatives $\left(110-\mathrm{L}_{1}\right.$, 76-s) of Rhizobium japonicum strains $311 \mathrm{~b} 110$ and 61A76. Specific activities of the key ammonia assimilatory enzymes, glutamine synthetase (EC 6.3.1.2), glutamate synthase (EC 2.6.1.53) and glutamate dehydrogenase (EC 1.4.1.2), were determined in aerobic, microaerophilic and bacteroid cell-free extracts. In aerobic culture, $110-\mathrm{L}_{\mathbf{1}}$ and $76-\mathrm{s}$ assimilated more ammonia than 110-I and 76-Ns because of apparent twofold or greater assimilatory enzyme activities. Specific ammonia assimilatory enzyme activities were 10- to 100 fold lower for all derivatives in nitrogen-fixing microaerophilic and bacteroid cultures. In addition to these already low ammonia assimilatory activities, the assimilatory activities of 110-I and 76-NS were twofold lower than those of $110-\mathrm{L}_{1}$ and $76-\mathrm{s}$. The small colony types also excreted ammonia under nitrogen-fixing conditions.

These findings support the idea that rhizobia can simultaneously derepress nitrogenase biosynthesis whilst repressing ammonia assimilatory enzyme biosynthesis. This investigation has also linked the efficiency of ammonia assimilation with the efficiency of nitrogenase activity as an inverse function, i.e. those $R$. japonicum derivatives that fix greater amounts of nitrogen also assimilate less fixed nitrogen.
\end{abstract}

\section{INTRODUCTION}

Recent studies concerned with the regulation of symbiotic nitrogen fixation in the Rhizobium-legume association have focused on the fate of the fixed-nitrogen product, ammonia, and the key enzymes of its assimilation. Brown \& Dilworth (1975), Robertson, Warburton \& Farnden (1975) and Kurz, Rokosh \& LaRue (1975) have shown that several enzymes involved in ammonia assimilation have low specific activities during nitrogen fixation. These three studies together with the earlier report of Bergersen \& Turner (1967) indicated that fixed nitrogen was excreted as ammonia from the nodule bacteroids.

Using the recently developed technique of free-living nitrogen fixation (Keister, 1975; Keister \& Evans, 1976; Kurz \& LaRue, 1975; McComb, Elliot \& Dilworth, 1975; Pagan et al., 1975; Tjepkema \& Evans, 1975) with ${ }^{15} \mathrm{~N}$ analysis, O'Gara \& Shanmugam (1976) demonstrated that most fixed nitrogen in liquid cultures of rhizobia was exported into the cell supernatant as $\mathrm{NH}_{4}{ }^{+}$. This observation led to a model of symbiotic nitrogen fixation in which rhizobia export fixed nitrogen as $\mathrm{NH}_{4}{ }^{+}$by simultaneously derepressing their nif genes whilst repressing genes of $\mathrm{NH}_{4}{ }^{+}$assimilation.

Previous reports from our laboratory (Kuykendall \& Elkan, 1976; Upchurch \& Elkan, 1977) have described the isolation and partial characterization of colony type derivatives from pure strains of Rhizobium japonicum. These clones, which differ in morphology and carbohydrate metabolism, also differ in symbiotic and non-associative nitrogen fixation. In 
view of the reports (Bishop et al., 1976; Brill, 1975; O'Gara \& Shanmugam, 1976) linking the reactions of ammonia assimilation to the control of nitrogenase activity, we have studied the activities of glutamine synthetase [EC 6.3.1.2; L-glutamate:ammonia ligase (ADPforming)], glutamate synthase [EC 2.6.1.53; L-glutamine:2-oxoglutarate aminotransferase (NADPH-oxidizing)] and glutamate dehydrogenase [EC 1.4.1.2; L-glutamate:NAD ${ }^{+}$ oxidoreductase (deaminating)] in cell-free extracts of these colony derivatives. In this paper we describe the patterns of ammonia assimilation for cultures of two previously described sets of colony derivatives of strains $3 \mathrm{I} 1 \mathrm{~b} 110$ and $61 \mathrm{~A} 76$ grown under aerobic or under microaerophilic conditions. Comparisons are made with enzyme activities found in bacteroid extracts from appropriately infected soybean root nodules.

\section{METHODS}

Bacterial strains. Rhizobium japonicum colony types of strain $311 \mathrm{~b} 110$ were obtained from Dr L. D. Kuykendall (U.S. Department of Agriculture, Beltsville, Maryland, U.S.A.). Rhizobium japonicum strain 61 A76 was obtained from Dr J. C. Burton (Nitragin Co., Milwaukee, Wisconsin, U.S.A.). Colony types from this strain were isolated as described by Upchurch \& Elkan (1977).

Media. Cultures were maintained on slopes of yeast extract/mannitol (YEM) (Lillich \& Elkan, 1968). The HEPES/MES buffered medium (HMG) of Upchurch \& Elkan (1977) was used for aerobic growth [HEPES: $N$-2-hydroxyethylpiperazine- $N$-2-ethanesulphonic acid; and MES: 2-( $N$-morpholino)ethanesulphonic acid were obtained from Sigma]; this medium contained $0.5 \%(\mathrm{w} / \mathrm{v})$ potassium gluconate and $0.025 \%(\mathrm{w} / \mathrm{v})$ yeast extract.

The M-HMG medium for free-living microaerophilic culture of $R$. japonicum was identical to HMG medium except that it did not contain $\mathrm{NH}_{4} \mathrm{Cl}$ and $30 \mu \mathrm{M}-\mathrm{Na}_{2} \mathrm{MoO}_{4}$ and $0 \cdot 1 \mathrm{~mm}$-EDTA were added.

Bacterial growth. Mid-exponential phase cells grown in HMG medium were harvested by centrifuging at $10000 \mathrm{~g}$ for $10 \mathrm{~min}$. The cells were washed once in HEPES/MES salts and resuspended in an equal volume of sterile HEPES/MES mineral salts. One $\mathrm{ml}$ of the suspension was inoculated into $50 \mathrm{ml}$ of fresh HMG medium containing $260 \mu \mathrm{g} \mathrm{NH}_{4} \mathrm{Cl} \mathrm{ml}^{-1}$ in $300 \mathrm{ml}$ side-arm flasks. At intervals, culture densities were determined using a Klett-Summerson colorimeter (red filter), and $1 \mathrm{ml}$ culture samples were aseptically removed for ammonia determinations. Fifty $\mathrm{ml}$ cultures were harvested after about $120 \mathrm{~h}$ of growth (late-exponential phase) for analysis of the enzymes of ammonia assimilation.

Microaerophilic growth and measurement of nitrogenase activity. Colony types were grown under microaerophilic conditions in the presence of nitrogen and acetylene in liquid medium using modifications (Upchurch \& Elkan, 1977) of the procedures of Tjepkema \& Evans (1975) and Keister (1975). For nitrogenase derepression studies, triplicate test-tube cultures were removed from the incubator at time zero and at daily intervals throughout the 7 day induction period. Cultures were analysed for nitrogenase activity (acetylene reduction), cell density (Klett-Summerson colorimeter) and extracellular ammonia.

To assay the enzymes of ammmonia assimilation in microaerophilic nitrogen-fixing cultures, 10 identical test-tube cultures of each colony type were incubated for $120 \mathrm{~h}$ and then analysed individually for nitrogenase activity as described above. The mean nitrogenase activity was determined from the 10 replicates and expressed as nmol acetylene reduced per tube. After the nitrogenase assays were completed, the cultures were combined and injected into serum stoppered $50 \mathrm{ml}$ Erlenmeyer flasks which were flushed with nitrogen and then placed in an ice bath until cell extracts were made.

Symbiotic nitrogen fixing activity. Growth chamber experiments using the Lee variety of soybean and the colony types of $R$. japonicum strains $311 \mathrm{~b} 110$ and $61 \mathrm{~A} 76$ were performed over $35 \mathrm{~d}$ as described by Upchurch \& Elkan (1977). Symbiotic nitrogenase activity was expressed as nmol acetylene reduced $\mathrm{h}^{-1}$ (mg dry wt nodule tissue $)^{-1}$. The nodules used were the same as those used to prepare extracts for ammonia assimilatory enzymes.

Preparation of bacteroids. Soybean root nodules (approx. $1 \mathrm{~g}$ ) were collected from plants infected with each colony type and bacteroids were prepared from these nodules by the method of Bishop et al. (1976) except that $0 \cdot 1 \mathrm{M}$-HEPES $/ 0 \cdot 2 \mathrm{M}$-sucrose buffer was used instead of the phosphate/sucrose $(\mathrm{pH} \mathrm{7.6)}$ buffer. The supernatant fractions from the nodule macerates were frozen for subsequent ammonia analyses. Approximately $100 \mathrm{mg}$ of the bacteroid samples were suspended in $2.5 \mathrm{ml}$ of the HEPES/sucrose buffer. These suspensions were injected into serum-stoppered $10 \mathrm{ml}$ Erlenmeyer flasks, flushed with nitrogen and then placed in an ice bath until cell-free extracts were made.

Preparation of cell-free extracts. Rhizobium japonicum, whether from aerobic, microaerophilic or bacteroid cultures, was harvested by centrifugation at $10000 \mathrm{~g}$ for $10 \mathrm{~min}$, washed twice and then resuspended in $2.5 \mathrm{ml}$ of $0.05 \mathrm{M}-\mathrm{K}^{+}$-HEPES buffer ( $\mathrm{pH} \mathrm{7.5)}$. These cells were then disrupted by sonication three times for 


\section{Table 1. Summary of properties characteristic of the derivatives used in this investigation}

The isolation of these colony types and their properties have been described by Kuykendall \& Elkan (1976) and Upchurch \& Elkan (1977).

Rhizobium japonicum derivative

\begin{tabular}{|c|c|c|c|c|}
\hline Property & $110-L_{1}$ & 110-I & 76-s & 76-Ns \\
\hline $\begin{array}{l}\text { Relative colony } \\
\text { size (mm diam.) }\end{array}$ & $4-5$ & $0 \cdot 5-1$ & $5-6$ & $1-2$ \\
\hline $\begin{array}{l}\text { Basis of colony } \\
\text { morphology on } \\
\text { YEM/HM medium }\end{array}$ & $\begin{array}{l}\text { Utilizes } \\
\text { D-mannitol }\end{array}$ & $\begin{array}{l}\text { Does not } \\
\text { utilize } \\
\text { D-mannitol }\end{array}$ & $\begin{array}{l}\text { Produces } \\
\text { extracellular } \\
\text { polysaccharides }\end{array}$ & $\begin{array}{l}\text { Does not produce } \\
\text { extracellular } \\
\text { polysaccharides }\end{array}$ \\
\hline $\begin{array}{l}\text { Ability to } \\
\text { nodulate Lee } \\
\text { soybeans }\end{array}$ & + & + & + & + \\
\hline $\begin{array}{l}\text { Symbiotic nitrogen } \\
\text { fixation }\end{array}$ & Low & High & Low & High \\
\hline $\begin{array}{l}\text { Free-living nitrogen } \\
\text { fixation }\end{array}$ & Low & High & Low & High \\
\hline
\end{tabular}

1 min (Branson Sonifier) with $30 \mathrm{~s}$ intervals during which the probe was chilled in an ice-water bath. Extracts were cleared of cell debris by centrifuging at $20000 \mathrm{~g}$ for $20 \mathrm{~min}$ at $4{ }^{\circ} \mathrm{C}$. The clear, slightly amber fluid was used within $8 \mathrm{~h}$ for enzyme assays.

Enzyme assays. Glutamine synthetase was assayed by measuring the amount of $\gamma$-glutamyl hydroxamate formed in the presence of $\mathrm{Mn}^{2+}$ at $37^{\circ} \mathrm{C}$ for $15 \mathrm{~min}$ as described by Shapiro \& Stadtman (1970). Glutamate synthase and glutamate dehydrogenase were assayed by following the oxidation of either the reduced form of NAD or NADP as coenzymes at room temperature as described by Prusiner, Miller \& Valentine (1972). The reactions were started by NADH or NADPH addition, and endogenous oxidation was determined in separate experiments. The protein concentration in the extract preparations was estimated by the absorption method of Warburg and Christian as described by Layne (1957). Extract protein was always adjusted to approx. $100 \mu \mathrm{g}$ protein $\mathrm{ml}^{-1}$ in the assay mixtures.

Ammonia determination. Ammonia in the cell-free extract, bacteroid extract, nodule supernatant and culture supernatant was determined by the colorimetric method of Chaney \& Marbach (1962). Ammonia was expressed as $\mu \mathrm{g} \mathrm{ml}^{-1}$ relative to a curve relating $A_{625}$ with $\mathrm{NH}_{4} \mathrm{Cl}$ concentration.

\section{RESULTS AND DISCUSSION}

Previous studies (Kuykendall \& Elkan, 1976; Upchurch \& Elkan, 1977) in our laboratory have linked $R$. japonicum colony morphology to the level of symbiotic and free-living nitrogenase activity. The characteristics of colonies from $311 \mathrm{~b} 110$ differed from those of colonies from 61A76 (Table 1). On YEM/HM medium(Kuykendall \& Elkan, 1977; Upchurch \& Elkan, 1977), derivatives of strain 311b110 either did or did not utilize D-mannitol, whereas colony morphologies of $61 \mathrm{~A} 76$ formed on the same medium were independent of carbon source and reflected differences in polysaccharide production. A survey of several other sets of colony types indicated that the basis of colony size was due to either differences in mannitol utilization or polysaccharide production, and for that reason, the clones of 110 and 76 were used as representative cultures in the nitrogen metabolism experiments that follow. All four derivatives nodulated their soybean host plant.

Initial growth curve studies of the derivatives in aerobic HMG broth culture showed that types $110-\mathrm{L}_{1}$ and $76-\mathrm{s}$ reached slightly higher maximum turbidities while depleting the medium of ammonia at faster rates than 110-I and 76-NS (Fig. 1). Because subtle but clear differences in aerobic ammonia utilization and growth among the colony types were observed, the specific activities of the enzymes of ammonia assimilation in aerobic, microaerophilic and bacteroid cultures were measured. 


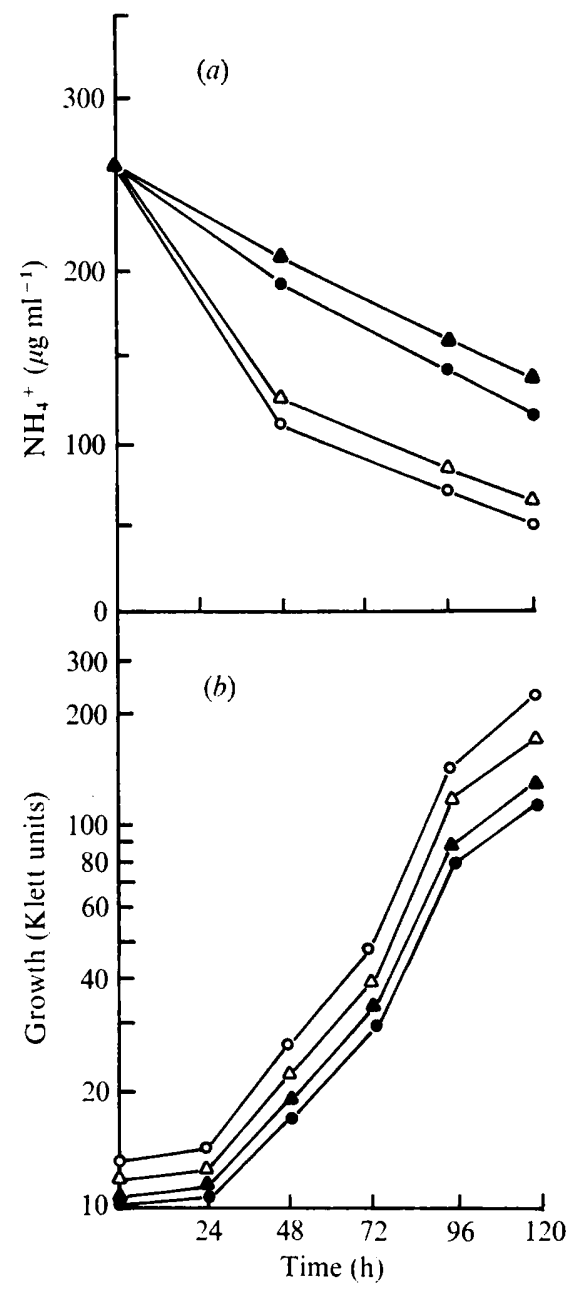

Fig. 1

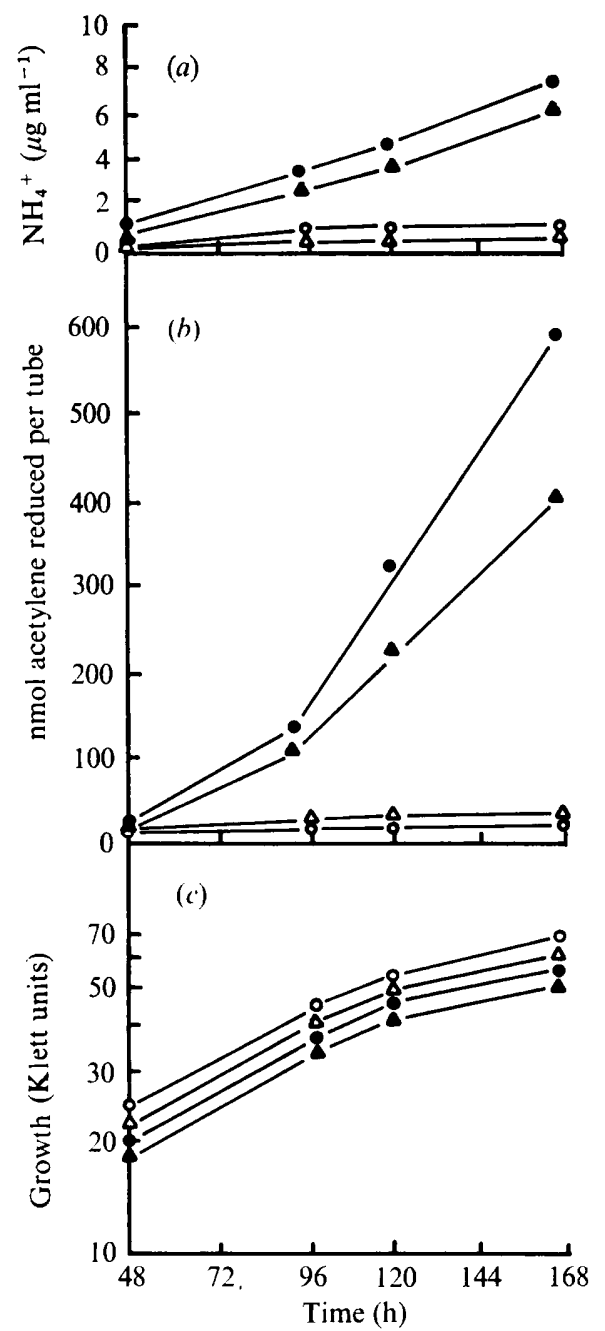

Fig. 2

Fig. 1. Time course of $(a)$ ammonia assimilation and $(b)$ growth of $R$. japonicum $311 b 110$ and

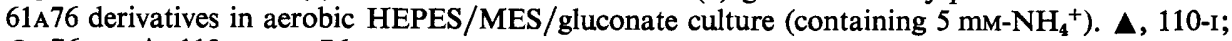
, 76-Ns; $\triangle, 110-\mathrm{L}_{1} ; \mathrm{O}, 76-\mathrm{s}$.

Fig. 2. Time course of $(a)$ ammonia export, $(b)$ nitrogenase activity (acetylene reduction) and $(c)$ growth of $R$. japonicum 311b110 and 61A76 derivatives cultured under an atmosphere of nitrogen/ acetylene (90:10, v/v). Symbols as in Fig. 1.

Ammonia assimilatory enzyme activities were measured in aerobic HMG broth cultures containing $5 \mathrm{~mm}_{-} \mathrm{NH}_{4}{ }^{+}$and $0.025 \%$ yeast extract. Highest specific enzyme activities were reached in the late-exponential phase of growth (approximately $120 \mathrm{~h}$ ). Nitrogenase activity was not detected in these cultures (Table 2). Glutamine synthetase, glutamate synthase and glutamate dehydrogenase activities were present in all derivatives. Interestingly, the activities of the large or slimy colony types $110-\mathrm{L}_{1}$ and $76-\mathrm{s}$ were higher for all three enzymes, i.e. twofold greater in glutamine synthetase and glutamate synthase (NADH) activities, and three to ninefold greater in glutamate dehydrogenase (NADH) activity. Although NADPHlinked glutamate synthase and dehydrogenase showed low activities (not always detected), their activity patterns followed the respective NADH activities. These enzyme data support and explain the previous utilization results (Fig. 1). 
Table 2. Activities of ammonia assimilatory enzymes in aerobic cultures of $R$. japonicum

\begin{tabular}{|c|c|c|c|c|c|c|}
\hline \multirow[b]{3}{*}{ Derivative } & \multirow{3}{*}{$\begin{array}{l}\text { nmol acetylene } \\
\text { reduced per tube* }\end{array}$} & \multirow{3}{*}{$\begin{array}{l}\text { Glutamine } \\
\text { synthetase }\end{array}$} & \multicolumn{3}{|c|}{$\begin{array}{c}\text { Specific activity } \dagger \\
{\left[\mathrm{nmol} \mathrm{min}^{-1}(\mathrm{mg} \text { protein })^{-1}\right]}\end{array}$} & \\
\hline & & & \multicolumn{2}{|c|}{$\begin{array}{l}\text { Glutamate } \\
\text { synthase }\end{array}$} & \multicolumn{2}{|c|}{$\begin{array}{c}\text { Glutamate } \\
\text { dehydrogenase }\end{array}$} \\
\hline & & & NADH & NADPH & NADH & NADPH \\
\hline $\begin{array}{l}110-\mathrm{L}_{1} \\
110-\mathrm{I} \\
76-\mathrm{S} \\
76-\mathrm{NS}\end{array}$ & $\begin{array}{l}- \\
- \\
-\end{array}$ & $\begin{array}{r}1002 \\
488 \\
2024 \\
848\end{array}$ & $\begin{array}{r}20 \\
12 \\
18 \\
9\end{array}$ & $\begin{array}{r}14 \\
5 \\
18 \\
5\end{array}$ & $\begin{array}{r}25 \\
9 \\
28 \\
3\end{array}$ & $\begin{array}{l}7 \\
1 \\
2 \\
-\end{array}$ \\
\hline
\end{tabular}

-, Activity not detected.

* Assays were performed on $2.5 \mathrm{ml}$ of culture in test-tubes at $120 \mathrm{~h}$.

$\dagger$ Assimilatory enzyme activities were determined in extracts prepared from $50 \mathrm{ml} \mathrm{HMG}$ cultures at $120 \mathrm{~h}$.

Table 3. Activities of ammonia assimilatory enzymes in microaerophilic cultures of $R$. japonicum

\begin{tabular}{|c|c|c|c|c|c|c|}
\hline \multirow[b]{3}{*}{ Derivative } & \multirow{3}{*}{$\begin{array}{l}\text { nmol acetylene } \\
\text { reduced per tube* }\end{array}$} & \multicolumn{5}{|c|}{$\begin{array}{c}\text { Specific activity } \dagger \\
{\left[\mathrm{nmol} \mathrm{min}^{-1}(\mathrm{mg} \text { protein })^{-1}\right]}\end{array}$} \\
\hline & & \multirow{2}{*}{$\begin{array}{l}\text { Glutamine } \\
\text { synthetase }\end{array}$} & \multicolumn{2}{|c|}{$\begin{array}{c}\begin{array}{c}\text { Glutamate } \\
\text { synthase }\end{array} \\
\end{array}$} & \multicolumn{2}{|c|}{$\begin{array}{c}\text { Glutamate } \\
\text { dehydrogenase }\end{array}$} \\
\hline & & & NADH & NADPH & NADH & NADPH \\
\hline $\begin{array}{l}110-\mathrm{L}_{1} \\
110-\mathrm{I} \\
76-\mathrm{S} \\
76-\mathrm{NS}\end{array}$ & $\begin{array}{r}25 \\
307 \\
40 \\
275\end{array}$ & $\begin{array}{r}13 \\
4 \\
12 \\
3\end{array}$ & $\begin{array}{r}\quad 3 \\
-\quad 4 \\
<2\end{array}$ & $\begin{array}{l}<2 \\
- \\
<2 \\
<2\end{array}$ & $\begin{array}{r}2 \\
<2 \\
3 \\
<2\end{array}$ & $\begin{array}{l}- \\
- \\
-\end{array}$ \\
\hline
\end{tabular}

-, Activity not detected.

* Activities were determined in $168 \mathrm{~h}$ microaerophilic cultures and are the mean of three independent experiments.

$\dagger$ Assimilatory enzyme activities were determined in cell-free extracts of $168 \mathrm{~h}$ microaerophilic cultures and are the mean of three independent experiments.

Table 4. Activities of ammonia assimilatory enzymes in bacteroids of

R. japonicum

\begin{tabular}{|c|c|c|c|c|c|c|}
\hline \multirow[b]{3}{*}{ Derivative } & \multirow{3}{*}{$\begin{array}{l}\text { nmol acetylene } \\
\text { reduced } \mathrm{h}^{-1}(\mathrm{mg} \\
\text { nodule tissue })^{-1 *}\end{array}$} & \multicolumn{5}{|c|}{$\begin{array}{c}\text { Specific activity } \dagger \\
{\left[\mathrm{nmol} \mathrm{min}^{-1}(\mathrm{mg} \text { protein })^{-1}\right]}\end{array}$} \\
\hline & & \multirow{2}{*}{$\begin{array}{l}\text { Glutamine } \\
\text { synthetase }\end{array}$} & \multicolumn{2}{|c|}{$\begin{array}{c}\text { Glutamate } \\
\text { synthase }\end{array}$} & \multicolumn{2}{|c|}{$\begin{array}{c}\text { Glutamate } \\
\text { dehydrogenase }\end{array}$} \\
\hline & & & NADH & NADPH & NADH & NADPH \\
\hline $110-\mathrm{L}_{1}$ & 27 & 188 & 11 & 8 & 7 & 4 \\
\hline $110-\mathrm{I}$ & 119 & 99 & 6 & 3 & 3 & - \\
\hline $76-s$ & 18 & 168 & 8 & 7 & 10 & 2 \\
\hline 76-NS & 90 & 61 & 5 & 6 & 5 & 3 \\
\hline
\end{tabular}

-, Activity not detected.

* Activities are the mean of two separate plant experiments.

$\dagger$ Assimilatory enzyme activities are the mean of two separate plant experiments and were determined by assay of bacteroid extracts. 


\section{Table 5. The partitioning of ammonia in nodule bacteroids}

Ammonia determinations of nodule macerate supernatants and extracts are the mean of two independent experiments. Results expressed as $\mu \mathrm{g} \mathrm{NH}_{4}{ }^{+} \mathrm{ml}^{-1}$.

$\begin{array}{lcc}\text { Derivative } & \text { Nodule supernatant } & \text { Bacteroid extract } \\ 110-\mathrm{L}_{\mathbf{1}} & 13 \cdot 50 & 0 \cdot 23 \\ 110-\mathrm{I} & 20 \cdot 50 & 2 \cdot 80 \\ 76-\mathrm{S} & 6 \cdot 30 & 0 \cdot 05 \\ 76-\mathrm{NS} & 11 \cdot 60 & 0 \cdot 47\end{array}$

The fate of fixed nitrogen in microaerophilic cultures of the derivatives was investigated by time-course experiments. Results indicated that after $48 \mathrm{~h}$ incubation, acetylene reduction activity increased in a near linear fashion. Increases in nitrogenase activity were accompanied by the appearance of ammonia in the cell-free supernatants of these cultures (Fig. 2). Free-living cultures of the small colony types (110-I and 76-NS) were many fold more efficient and also excreted more ammonia than $110-\mathrm{L}_{1}$ and $76-\mathrm{s}$. Microaerophilic cultures of the derivatives grown under an argon/acetylene atmosphere also had similar patterns of acetylene reduction activity, but no appreciable ammonia in the supernatant was ever detected in cultures of 110-I and 76-NS.

Of the various enzyme activities of microaerophilic cultures, nitrogenase activity patterns in the non-associative cultures were as expected, with 110-I and 76-NS many fold more efficient than corresponding large or slimy colony types (Table 3). Assimilatory enzyme activities were much lower in these cultures. Glutamine synthetase activity was 10- to 100fold lower in microaerophilic culture as compared to aerobic culture. Glutamate synthase and glutamate dehydrogenase specific activities were near the limit of detection; in some cases neither NADH- nor NADPH-linked enzyme activities were detected. A consistent glutamine synthetase pattern was evident, i.e. 110- $\mathrm{L}_{1}$ and 76-s had higher while 110-I and 76-NS had lower assimilatory activities. The specific activities of glutamate synthase and glutamate dehydrogenase activity (NADH-linked), even though low, also followed a similar pattern. The levels of assimilatory activities detected in microaerophilic culture support the working model of nitrogenase regulation proposed by O'Gara \& Shanmugam (1976). Important differences were also revealed about the nitrogen metabolism of the colony derivatives. Colony types $110-\mathrm{I}$ and 76-NS were able to derepress their nif genes while concomitantly more efficiently repressing their assimilatory genes and thereby excreting more fixed $\mathrm{NH}_{4}{ }^{+}$nitrogen. From these observations with microaerophilic cultures, it is inferred that the linkage between ammonia assimilation and nitrogenase activity is less 'tight' in derivatives of $110-\mathrm{L}_{1}$ and $76-\mathrm{s}$.

The nitrogenase and ammonia assimilatory activities developed in bacteroids from the nodules of appropriately infected plants were also assayed (Table 4). Nitrogenase activity patterns were similar to those observed in the microaerophilic cultures (Table 3). Bacteroid assimilatory enzyme activities were also much lower than those detected in aerobic culture. Glutamine synthetase, glutamate synthase and glutamate dehydrogenase activities exhibited similar patterns to those observed in miroaerophilic cultures, i.e. the activities in 76-S and $110-\mathrm{L}_{1}$ were high whereas those in 76-NS and 110-I were low. The majority of soluble $\mathrm{NH}_{4}{ }^{+}$was found in the bacteroid cytosol fraction rather than in the bacteroid enzyme extract. Ammonia was found in higher concentration in the bacteroid cytosols of 110-I and 76-NS than in the cytosols of $110-\mathrm{L}_{1}$ and 76-s (see Table 5). These preliminary bacteroid studies thus confirmed our earlier observations made with the non-associative nitrogen-fixing systems.

Paper no. 5243 of the Journal Series of the North Carolina Agricultural Experiment Station, Raleigh, North Carolina. 


\section{REFERENCES}

Bergersen, I. J. \& TURNER, G. L. (1967). Nitrogen fixation by the bacteroid fraction of breis of soybean root nodules. Biochimica et biophysica acta 141, 507-515.

Bishop, P. E., Guevara, J. G., Engelke, J. A. \& Evans, H. J. (1976). Relation between glutamine synthetase and nitrogenase activities in the symbiotic association between Rhizobium japonicum and Glycine max. Plant Physiology 57, 542546.

BRILL, W. J. (1975). Regulation and genetics of bacterial nitrogen fixation. Annual Review of Microbiology 29, 109-129.

Brown, C. M. \& DilworTH, M. J. (1975). Ammonia assimilation by Rhizobium cultures and bacteroids. Journal of General Microbiology 86, 39-48.

Chaney, A. L. \& Marbach, E. P. (1962). Modified reagents for determination of urea and ammonia. Clinical Chemistry 8, 130-132.

KEISTER, D. L. (1975). Acetylene reduction by pure cultures of rhizobia. Journal of Bacteriology 123, 1265-1268.

Keister, D. L. \& Evans, W. R. (1976). Oxygen requirement for acetylene reduction by pure cultures of rhizobia. Journal of Bacteriology 129, 149-153.

Kurz, W. G. W. \& LA Rue, T. A. (1975). Nitrogenase activity in absence of plant host. Nature, London 256, 407-408.

Kurz, W. G. W., Rokosh, D. A. \& LA Rue, T. A. (1975). Enzymes of ammonia assimilation in Rhizobium leguminosarum bacteroids. Canadian Journal of Microbiology 21, 1009-1012.

KUYKendall, L. D. \& ElkaN, G. H. (1976). Rhizobium japonicum derivatives differing in nitrogen fixing efficiency and carbohydrate utilization. Applied and Environmental Microbiology 32, 511-519.

Kuykendall, L. D. \& Elkan, G. H. (1977). Some features of mannitol metabolism in Rhizobium japonicum. Journal of General Microbiology 98, 291-295.
LAYNE, E. (1957). Spectrophotometric and turbidometric methods for measuring protein. Methods in Enzymology 3, 447-454.

LILLICH, T. T. \& ElKAN, G. H. (1968). Evidence countering the role of polygalacturonase in invasion of root hairs of leguminous plants by Rhizobium spp. Canadian Journal of Microbiology 14, 617-625.

MсСомв, J. A., Elliot, J. \& Dilworth, M. J. (1975). Acetylene reduction by Rhizobium in pure culture. Nature, London 256, 409-410.

O'Gara, R. \& Shanmugam, K. T. (1976). Regulation of nitrogen fixation by Rhizobia export of fixed $\mathrm{N}_{2}$ as $\mathrm{NH}_{4}^{+}$. Biochimica et biophysica acta 437, 313-321.

Pagan, J. D., Child, J. J., Scrowcroft, W. R. \& GiBsoN, A. H. (1975). Nitrogen fixation by Rhizobium cultured on a defined medium. Nature, London 256, 406-407.

Prusiner, S., Miller, R. E. \& Valentine, R. C. (1972). Adenosine $3^{\prime}: 5^{\prime}$-cyclic monophosphate control of the enzymes of glutamine metabolism in Escherichia coli. Proceedings of the National Academy of Sciences of the United States of America 69, 2922-2926.

Robertson, J. G., Warburton, M. P. \& Farnden, W. J. F. (1975). Induction of glutamate synthetase during nodule development in lupin. FEBS Letters 55, 33-37.

Shapiro, B. M. \& Stadtman, E. R. (1970). Glutamine synthetase (E. coli). Methods in Enzymology 17A, 910-922.

TJEPKEMA, J. \& Evans, H. J. (1975). Nitrogen fixation by free-living Rhizobium in a defined liquid medium. Biochemical and Biophysical Research Communications 65, 625-628.

UpChuRCh, R. G. \& ElKaN, G. H. (1977). Comparison of colony morphology, salt tolerance and effectiveness in Rhizobium japonicum. Canadian Journal of Microbiology 23, 1118-1122. 